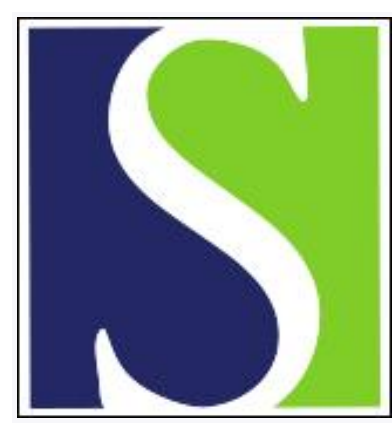

Scand J Work Environ Health 1993;19(6):399-404

https://doi.org/10.5271/sjweh.1455

Issue date: 01 Dec 1993

Multiple sclerosis and exposure to solvents, ionizing radiation and animals.

by Landtblom AM, Flodin U, Karlsson M, Palhagen S, Axelson O, Soderfeldt B

Affiliation: Department of Neurology, University Hospital, Linkoping, Sweden.

This article in PubMed: www.ncbi.nlm.nih.gov/pubmed/8153592

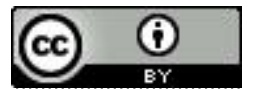




\title{
Multiple sclerosis and exposure to solvents, ionizing radiation and animals
}

\author{
by Anne-Marie Landtblom, MD, ${ }^{1}$ Ulf Flodin, MD, ${ }^{2}$ Magnus Karlsson, BSc, ${ }^{2}$ Sven Pålhagen, MD, ${ }^{3}$ \\ Olav Axelson, MD, ${ }^{2}$ Birgitta Söderfeldt, MD, ${ }^{1}$
}

\begin{abstract}
LANDTBLOM A-M, FLODIN U, KARLSSON M, PÅLHAGEN S, AXELSON O, SÖDERFELDT
B. Multiple sclerosis and exposure to solvents, ionizing radiation and animals. Scand $J$ Work Environ Health 1993;19:399-404. Earlier studies have indicated an association between multiple sclerosis and environmental factors, especially occupational exposure to solvents. The present study examined such relationships further. From medical files of hospitals in Kalmar and Jönköping, 91 cases of multiple sclerosis, diagnosed in 1983-1988, were identified from population registers corresponding to the catchment areas of the hospitals, and 348 referents were randomly drawn. The cases and referents answered a questionnaire concerning occupational exposure and animal contacts. The men had significantly elevated risks, determined from logistic odds ratios, for solvent exposure, occupational contact with dogs or cats, and leisure-time contact with caged birds. X-ray treatment and previous diseases were risk indicators among the women. For the men and women together, solvent exposure, radiological work, and previous diseases were associated with clearly elevated risks. Although the study concerned rather few subjects, the findings indicate that several exogenous factors might contribute to the development of multiple sclerosis.
\end{abstract}

Key terms: case-referent study, epidemiologic, exposure classification, occupational, questionnaire, radiological work.

Multiple sclerosis is an inflammatory disease of the central nervous system. It is characterized by primary destruction of myelin. The precise pathogenesis is unclear. Recent studies support the ideas that certain human leucocytlocus A (HLA) haplotypes imply increased susceptibility to multiple sclerosis $(1-5)$ and that infections $(6-15)$, for example, retrovirus (1618), may play a role in the pathogenesis. There are several observations regarding the associated occurrence of multiple sclerosis with other autoimmune disorders (19), like myasthenia gravis (20), thyroid disease (21), and Sjogren's syndrome (22), but also with such clearly HLA-linked conditions as ankylosing spondylitis (23) and narcolepsy $(24,25)$.

It is also well known that the incidence of multiple sclerosis varies with geographic latitude and that individual risk can be altered by changing residence before adolescence, the result being adoption of the incidence of the new location (26). Many studies have shown that animal contacts could mean a higher risk $(27-30)$, but in a later review of the etiologic importance of such contacts the results have been ambiguous, with some of the nonpositive studies

1 Department of Neurology, University Hospital, S-581 85 Linköping, Sweden.

2 Department of Occupational Medicine, University Hospital, S-581 85 Linköping, Sweden.

3 Department of Internal Medicine, Division of Neurology, Ryhov Hospital, S-551 85 Jönköping, Sweden.

Reprint requests to: $\mathrm{Dr}$ AM Landtblom, Department of Neurology, University Hospital, S-581 85 Linköping, Sweden. bearing more weight (31). Hence the pathogenesis is likely to be complex - both genetic and environmental factors may be involved and interact (32).

Regarding exogenous factors, exposure to organic solvents among Italian shoe and leather workers was associated with an increased risk of multiple sclerosis (33). A previous study from our group (34) showed that occupational exposure to solvents, especially in combination with welding, was associated with an increased risk of multiple sclerosis among men. For both genders X-ray examination until five years before diagnosis occurred more frequently than in a reference group. There are also reports of an increased risk among health care workers (35) and persons working in paper manufacturing (36).

General determinants affecting the occurrence of the disease have been discussed with respect to the great variation in risk with regard to geographic and climatologic distribution (37). Examples of such determinants are water chemistry (38) and ultraviolet radiation (39), but also dietary $(40,41)$ and socioeconomic variables have been suggested as impor$\operatorname{tant}(31)$.

Population surveys repeatedly show that multiple sclerosis appears more often among women than among men. According to recent reports the difference can be two- to threefold (42).

The aim of the present study was to determine whether the results of the earlier Swedish study (34) could be reproduced in another adjacent population. Thus potential risk factors like exposure to organic solvents, welding, radiation, and animal contacts were of a priori interest in this study. 


\section{Subjects and methods}

\section{Cases}

In 1989, cases of multiple sclerosis were collected from the patient files of the neurological departments of the hospitals in Jönköping and Kalmar, representing two administrative provinces with a base population of 540000 individuals. There are no other neurological departments in the area, and in the Swedish medical system it is not likely that this type of patient would be diagnosed by private practitioners. Therefore there should have been minimal selection bias in the study. All of the cases identified had been diagnosed in 1983 through 1988. Furthermore, the cases were labeled as definite multiple sclerosis, fulfilling the criteria by Schumacher et al (43), or as probable or possible multiple sclerosis according to the criteria of Rose et al (44).

Altogether 97 persons aged $20-61$ years at diagnosis were given case status. Of these, 91 responded to the questionnaire $(94 \%)$. The rest refused to participate. Of the responding subjects the diagnosis had been definite for 48 , probable for 21 , and possible for 22 .

\section{Referents}

The referents were randomly drawn from the population registers of the administrative provinces of Jönköping and Kalmar (ie, corresponding to the catchment areas of the hospitals). They were 20 to 65 years of age in 1989 when the selection was performed. Out of 400 selected referents, 348 agreed to be included in the study (ie, the reply frequency was $87 \%$ ). The deficit was due to refusal to participate.

\section{Assessment of exposure}

Information about various types of exposure among the cases and referents was obtained by an identical procedure and without revealing the purpose of the study with respect to multiple sclerosis. A ten-page questionnaire preceded by an introductory letter was sent to the subjects. The questionnaire contained 16 main questions, 10 of which focused on occupational exposures. Some of the questions were further subspecified with regard to certain details. Five questions were devoted to medical care, particularly to the use of drugs, $\mathrm{X}$-ray treatment, and X-ray examinations.

A minimum criterion of one year was required for exposure time, along with a five-year latency period (ie, the last five years of exposure were disregarded both for the cases and the referents). The mean year of diagnosis was 1986. In the consideration of latency, this year was taken as an anchor point in time for the referents with regard to the various exposures.

Information about solvent exposure in qualitative terms was directly obtained from the questionnaires. To avoid overreporting of the exposure, especially among the cases, all exposure data of a priori inter- est were critically checked for credibility in telephone interviews with both the cases and the referents. The quantitative classification had five intensity categories formed on the basis of an appraisal applied in some of our other studies, and as originally suggested by Ravnskov et al (45). Hence five categories of increasing intensity were created for solvent exposure, from category $0=$ not exposed to category 4 = highest intensity (eg, floor layers). An example of an occupation in category 1 would be staff at day nurseries, one for category 2 would be cleaner, and for category 3 repairman. Categories 0 and 1 (ie, not or only very slightly exposed subjects) were considered practically unexposed. Categories 2 , 3 , and 4 were merged into an exposed group since the number of subjects was too small for separate analyses of single exposure categories.

\section{Statistical methods}

The statistical analyses of the data were based on stratification by age and application of MantelHaenszel procedures (46). The approximate confidence intervals of the Mantel-Haenszel rate ratios (odds ratios) were calculated according to Miettinen (47). Multiple logistic regression, based on the Epilog Plus statistical package (48), was used as an additional method in the data analyses for the simultaneous control of several potentially confounding factors. The data for the men and women were analyzed separately since female gender appeared to be a determinant per se (34).

\section{Results}

The Mantel-Haenszel rate ratios were elevated among the men for occupational solvent exposure in general, and specifically for exposure to kerosene, with its lower $95 \%$ confidence limit exceeding unity. Occupational exposure to domestic animals, like dogs, cats, horses, swine, and poultry, were significant risk indicators similar to caged birds at home (table 1), whereas contact with pet dogs or cats were not (table 2). Among the women occupational solvent and radiological exposures appeared as less clear risk factors (table 3 ) since the confidence interval included unity and the results were similar for animal contacts. X-ray treatment occurred for five cases and no referents, giving a formally infinite risk. Various previous diseases taken together were more common among the cases than the referents. Similar results were obtained by multiple logistic regression, which resulted in risk estimates with lower $95 \%$ confidence limits exceeding unity for solvent exposure, occupational contact with dogs or cats and leisure-time contact with caged birds among the men. Since exposure to farm animals was complex, it was impossible to analyze the separate effects from single species; instead, we had to merge all types of farm animals in the multiple logistic regression (ta- 
Table 1. Exposure regarding selected risk indicators among the cases of multiple sclerosis and the referents, along with estimates of the Mantel-Haenszel rate-ratio for the men. The underlying stratification by age has been omitted. ${ }^{a}$ For an explanation of the solvent exposure category, see the section Assessment of Exposure in the text. ( $95 \% \mathrm{CI}=95 \%$ confidence interval)

\begin{tabular}{|c|c|c|c|c|}
\hline Exposure & $\begin{array}{c}\text { Cases } \\
(\mathrm{N}=24)\end{array}$ & $\begin{array}{l}\text { Referents } \\
(\mathrm{N}=172)\end{array}$ & $\begin{array}{l}\text { Mantel- } \\
\text { Haenszel } \\
\text { rate ratio }\end{array}$ & $95 \% \mathrm{Cl}$ \\
\hline $\begin{array}{l}\text { Solvent exposure } \\
\text { (categories } 2+3+4 \\
\text { versus } 0+1 \text { ) }\end{array}$ & 14 & 53 & 3.4 & $1.2-9.4$ \\
\hline Kerosene & 7 & 7 & 9.3 & $2.4-35$ \\
\hline \multicolumn{5}{|c|}{$\begin{array}{l}\text { Occupational exposure } \\
\text { to animals }\end{array}$} \\
\hline $\begin{array}{l}\text { Dogs } \\
\text { Cats }\end{array}$ & $\begin{array}{l}3 \\
4\end{array}$ & $\begin{array}{l}3 \\
3\end{array}$ & $\underset{15}{9.9}$ & $\begin{array}{l}1.4-77 \\
2.3-115\end{array}$ \\
\hline $\begin{array}{l}\text { Poultry } \\
\text { Horses } \\
\text { Swine }\end{array}$ & $\begin{array}{l}5 \\
5 \\
5\end{array}$ & $\begin{array}{r}3 \\
9 \\
11\end{array}$ & $\begin{array}{l}21 \\
6.5 \\
4.5\end{array}$ & $\begin{array}{l}3.5-183 \\
1.4-28 \\
1.1-17.6\end{array}$ \\
\hline Pet caged bird & 6 & 14 & 3.7 & $1.1-12.6$ \\
\hline
\end{tabular}

ble 4). Similarly, as shown in table 4, X-ray treatment and various previous diseases as a group were risk indicators among the women. For the men and women together solvent exposure, radiological work, and various previous diseases were associated with clearly elevated risk (table 4).

Dividing the material into the subgroups of multiple sclerosis (ie, possible, probable and definite) resulted in small numbers without any distinguishable pattern in the rate ratios when calculable. The three subgroups were therefore merged in all of the analyses.

\section{Discussion}

\section{Methodological aspects}

This study had a primary study base since the subjects were recruited from the population of two adjacent administrative provinces (49). Hence the cases of multiple sclerosis were searched for in the patient files of the two, and only existing neurologic departments of these provinces and the referents were randomly drawn from the population registers of the same areas. Therefore it seems unlikely that any selection of cases conditionally on exposure should have occurred, nor is any selection bias likely with regard to the referents.

A five-year time criterion was applied in order to avoid the possibility that the disease itself would cause the cases to have particular exposures (eg, exposure to X-rays).

The proportion of men with multiple sclerosis in our material was low, $26 \%$, which is in agreement with recently reported values (42).

Since female gender is associated with multiple sclerosis, most of the analyses were performed separately for the men and women to avoid confound-
Table 2. Status or exposure (examples of nonsignificant risk indicators of some interest were selected for this table) among the cases and the referents, along with estimates of the Mantel-Haenszel rate-ratios for the men. The underlying stratification by age has not been shown in the table. ${ }^{a}(95 \%$ $\mathrm{Cl}=95 \%$ confidence interval)

\begin{tabular}{lcccc}
\hline Status or exposure & $\begin{array}{c}\text { Cases } \\
(\mathrm{N}=24)\end{array}$ & $\begin{array}{c}\text { Referents } \\
(\mathrm{N}=172)\end{array}$ & $\begin{array}{c}\text { Mantel- } \\
\text { Haenszel } \\
\text { rate ratio }\end{array}$ & $95 \% \mathrm{Cl}$ \\
\hline $\begin{array}{l}\text { Welding } \\
\text { Radiological work }\end{array}$ & 4 & 21 & 1.4 & $0.4-4.3$ \\
Gasoline & 2 & 2 & 7 & $0.7-83$ \\
Thinner & 5 & 15 & 2.9 & $0.7-10.5$ \\
Farming & 6 & 19 & 2.6 & $0.7-7.9$ \\
Cows & 4 & 15 & 2.4 & $0.5-9.2$ \\
Herbicides & 5 & 16 & 2.9 & $0.8-10$ \\
Pets & 1 & 7 & 0.9 & $0.1-7.6$ \\
$\quad$ Dog & & & & 0.3 \\
$\quad$ Cat & 9 & 62 & 1.1 & $0.3-2.7$ \\
X-ray treatment & - & 42 & 1.3 & $0.4-3.7$ \\
Previous diseases & 2 & -15 & 0 & - \\
Smoking & 6 & 46 & 0.9 & $0.1-4.3$ \\
\hline
\end{tabular}

a The subjects were stratified into age groups $20-34,35-49$, and $50-65$ years.

Table 3. Status or exposure among the cases and referents, along with estimates of the Mantel-Haenszel rate ratio, for the women. The underlying stratification by age has not been shown. ${ }^{\mathrm{a}}$

\begin{tabular}{|c|c|c|c|c|}
\hline Status or exposure & $\begin{array}{c}\text { Cases } \\
(\mathrm{N}=67)\end{array}$ & $\begin{array}{l}\text { Referents } \\
(\mathrm{N}=176)\end{array}$ & $\begin{array}{l}\text { Mantel. } \\
\text { Haenszel } \\
\text { rate ratio }\end{array}$ & $95 \% \mathrm{Cl}$ \\
\hline $\begin{array}{l}\text { Solvent exposure } \\
\text { (categories } \\
2+3+4 \text { versus } \\
0+1 \text { ) } \\
\text { Kerosene } \\
\text { Gasoline } \\
\text { Thinner }\end{array}$ & $\frac{10}{1}$ & $\begin{array}{l}9 \\
1 \\
1 \\
5\end{array}$ & $\begin{array}{l}2.8 \\
0 \\
2.2 \\
1.6\end{array}$ & $\begin{array}{l}0.9-8.0 \\
0.1-175 \\
0.2-8.5\end{array}$ \\
\hline $\begin{array}{l}\text { Welding } \\
\text { Radiological work } \\
\text { X-ray treatment } \\
\text { Metal work }\end{array}$ & $\begin{array}{l}- \\
4 \\
5 \\
5\end{array}$ & $\frac{\overline{1}}{2}$ & $\begin{array}{l}0 \\
8.4 \\
\infty \\
6.4\end{array}$ & $\begin{array}{l}0.8-209 \\
0.9-47\end{array}$ \\
\hline $\begin{array}{l}\text { Farming } \\
\text { Occupational exposure } \\
\text { to animals }\end{array}$ & 4 & 17 & 0.7 & $0.1-2.5$ \\
\hline $\begin{array}{l}\text { Dogs } \\
\text { Cats } \\
\text { Poultry }\end{array}$ & $\begin{array}{l}4 \\
5 \\
8\end{array}$ & $\begin{array}{r}5 \\
11 \\
15\end{array}$ & $\begin{array}{l}2.2 \\
1.3 \\
1.7\end{array}$ & $\begin{array}{l}0.4-17 \\
0.3-4.4 \\
0.5-4.7\end{array}$ \\
\hline $\begin{array}{l}\text { Horses } \\
\text { Swine } \\
\text { Cows } \\
\text { Herbicides }\end{array}$ & $\begin{array}{r}6 \\
7 \\
8 \\
-\end{array}$ & $\begin{array}{r}14 \\
17 \\
19 \\
2\end{array}$ & $\begin{array}{l}1.3 \\
1.3 \\
1.3 \\
0\end{array}$ & $\begin{array}{c}0.3-4.0 \\
0.4-3.6 \\
0.4-3.5 \\
.\end{array}$ \\
\hline \multicolumn{5}{|l|}{ Pets } \\
\hline $\begin{array}{l}\text { Dog } \\
\text { Cat } \\
\text { Caged bird }\end{array}$ & $\begin{array}{l}29 \\
25 \\
13\end{array}$ & $\begin{array}{l}67 \\
65 \\
27\end{array}$ & $\begin{array}{l}1.2 \\
1.0 \\
1.3\end{array}$ & $\begin{array}{l}0.7-2.2 \\
0.5-2.0 \\
0.6-2.9\end{array}$ \\
\hline Smoking & 23 & 45 & 1.4 & $0.7-2.7$ \\
\hline Previous diseases & 20 & 20 & 3.3 & $1.5-7.5$ \\
\hline
\end{tabular}

a The subjects were stratified into age groups $20-34,35-49,50-65$ years.

ing from gender when occupational exposures associated with gender were considered. In the correlation analyses of various exposures among the referents it turned out that there was an association between some exposures of interest, most strongly between solvents and farming, and a possibility for confounding existed. Therefore multiple logistic regression was performed as well, but it resulted in rela- 
Table 4. Logistic odds ratios for exposure of interest among the cases of multiple sclerosis and the referents with the men and women both separately and combined.

\begin{tabular}{|c|c|c|c|c|c|c|}
\hline \multirow{2}{*}{ Exposure } & \multicolumn{2}{|c|}{ Women } & \multicolumn{2}{|c|}{ Men } & \multicolumn{2}{|c|}{$\begin{array}{l}\text { Women and } \\
\text { men combined }\end{array}$} \\
\hline & $\begin{array}{l}\text { Odds } \\
\text { ratio }\end{array}$ & $95 \% \mathrm{Cl}$ & $\begin{array}{l}\text { Odds } \\
\text { ratio }\end{array}$ & $95 \% \mathrm{Cl}$ & $\begin{array}{l}\text { Odds } \\
\text { ratio }\end{array}$ & $95 \% \mathrm{Cl}$ \\
\hline $\begin{array}{l}\text { Solvent exposure } \\
\text { Radiological work } \\
\text { Previous diseases } \\
\text { Metal work }\end{array}$ & $\begin{array}{l}1.9 \\
8.2 \\
3.6 \\
5.8\end{array}$ & $\begin{array}{l}0.6-5.7 \\
0.7-90 \\
1.6-7.7 \\
0.9-35\end{array}$ & $\begin{array}{l}3.3 \\
7.6 \\
1.4\end{array}$ & $\begin{array}{l}1.1-9.5 \\
0.8-70 \\
0.4-4.0\end{array}$ & $\begin{array}{l}2.8 \\
7.5 \\
2.5 \\
1.9\end{array}$ & $\begin{array}{l}1.3-5.5 \\
1.5-35 \\
1.2-4.8 \\
0.8-4.5\end{array}$ \\
\hline $\begin{array}{l}\text { Farming } \\
\text { Plastic work } \\
\text { Occupational exposure to cats or dogs } \\
\text { Occupational exposure to horses, hens, cows or swine }\end{array}$ & $\begin{array}{l}0.5 \\
1.2 \\
1.0 \\
1.5\end{array}$ & $\begin{array}{l}0.1-2.8 \\
0.2-6.3 \\
0.2-6 \\
0.2-9.4\end{array}$ & $\begin{array}{c}1.5 \\
1.7 \\
18 \\
0.6\end{array}$ & $\begin{array}{l}0.1-18 \\
0.3-8.1 \\
1.3-265 \\
0.1-10.1\end{array}$ & $\begin{array}{l}0.7 \\
1.7 \\
2.1 \\
1.2\end{array}$ & $\begin{array}{l}0.1-2.9 \\
0.5-4.9 \\
0.5-8.3 \\
0.2-5.1\end{array}$ \\
\hline \multicolumn{7}{|l|}{ Pets } \\
\hline $\begin{array}{l}\text { Dog } \\
\text { Cat } \\
\text { Caged bird }\end{array}$ & $\begin{array}{l}1.3 \\
0.9 \\
1.4\end{array}$ & $\begin{array}{l}0.6-2.4 \\
0.4-1.7 \\
0.6-3.1\end{array}$ & $\begin{array}{l}0.8 \\
1.1 \\
4.4\end{array}$ & $\begin{array}{l}0.2-2.2 \\
0.3-3.5 \\
1.1-16\end{array}$ & $\begin{array}{l}1.2 \\
0.9 \\
1.8\end{array}$ & $\begin{array}{l}0.6-1.8 \\
0.5-1.5 \\
0.9-3.5\end{array}$ \\
\hline X-ray treatment & $\infty$ & . & 0 & . & 0 & . \\
\hline $\begin{array}{l}\text { Welding } \\
\text { Female gender }\end{array}$ & $\begin{array}{l}0 \\
0\end{array}$ & . & $\begin{array}{l}0.8 \\
0\end{array}$ & $0.1-3.4$ & $\begin{array}{l}0.7 \\
4.4\end{array}$ & $\begin{array}{l}0.2-2.7 \\
2.2-8.7\end{array}$ \\
\hline
\end{tabular}

a According to logit $f(y)$ caseleferent $=10.3609+0.6640$ (metal work) -0.3368 (farming) +1.0133 (solvent) -0.3061 (welding) + 0.5053 (plastic work) +2.0167 (radiological work) +0.7624 (occupational exposure to dogs or cats) +0.2179 (horse/hen/swine/ cow) +0.0951 (pet; dog) -0.1027 (pet; cat) +0.5976 (caged bird) +0.9243 (previous diseases) +1.4763 (female gender) +0.0039 (age $34-49$ years) -0.3844 (age $\geq 50$ years).

tively little new information, except for almost eliminating the effect of animal contacts.

\section{Etiologic aspects}

Solvents. Occupational solvent exposure in general, and specifically exposure to kerosene, turned out to be associated with increased risk. In our previous study (34) white spirit gave a significantly high risk for multiple sclerosis. These types of solvents are closely related and are both mixtures of mainly aliphatic hydrocarbons, but they also include a few percent each of many different aromatics. Kerosene has a higher flame point $\left(81^{\circ} \mathrm{C}\right)$ than white spirit $\left(57^{\circ} \mathrm{C}\right)$. It is not unreasonable to assume that there was no clear distinction between these two solvents in the answers to our questionnaire since these solvents are probably rather intermixed in Swedish colloquial language. They are also used to a great extent for the same purposes among mechanics and repair workers.

Cerebrospinal fluid analyses of men with heavy solvent exposure have in some cases shown bloodbrain barrier dysfunction indicated by leakage of protein into the cerebrospinal fluid (50), but the findings are inconsistent (51). Under the hypothesis that multiple sclerosis ultimately has a viral etiology, one could speculate of the possibility of solvents enhancing viral entrance to the nervous system.

$X$ rays. This study indicates that exposure to ionizing radiation might have an increased risk for multiple sclerosis, as observed both for patients treated with $\mathrm{X}$ rays and for radiological personnel. There were five cases of multiple sclerosis being treated with $\mathrm{X}$ rays until five years before diagnosis, but no referents had had such an experience. A previous study (34) showed an increased risk in connection with $\mathrm{X}$-ray examinations until five years before diagnosis. This finding was primarily interpreted as simply reflecting the fact that a number of investigations have to be made at an early stage of the disease when the diagnosis is still unclear. However, together with the earlier findings, the new data obtained in this study support the alternative that radiation per se might contribute to the development of multiple sclerosis, since we now have shown an increased risk for multiple sclerosis also in two other situations (ie, X-ray treatment and occupational exposure). Since both ultraviolet and ionizing radiation can induce viral synthesis in lysogenic bacteria $(52$, 53 ), one could speculate that radiation might cause primary damage and therefore play an inducing role in a two-step pathogenetic development of multiple sclerosis (ie, if there is a viral or immunologic etiology as well).

Animal contacts. Our results give no clear support to earlier findings $(12,27-30,34)$ that animal contact may be a risk factor for developing multiple sclerosis. In the pathogenetic discussion of multiple sclerosis, several infectious agents have been suggested as directly or indirectly inducing or precipitating the development of multiple sclerosis $(6-15)$. By univariate analyses a raised risk of multiple sclerosis also appeared in this study among the men occupa- 
tionally exposed to animals. The question arises of why occupational contact with dogs and cats incurs a risk, whereas "pet contact" does not. However, the formal risk for occupational contact with some animals (cow, swine, horse, poultry) as observed in the univariate analyses appears to be confounded by solvent use among farmers (mostly chain-saw petrol) since this risk was almost eliminated by the logistic regression analysis. For occupational contact with dogs and cats there remained a significant risk in the multiple logistic regression analysis which cannot be explained by confounding by solvents.

Previous diseases. In order to detect possible connections between multiple sclerosis and other diseases (eg, inflammatory or infectious in character) the questionnaire contained one question concerning "any long-lasting or serious diseases." In the statistical analysis we focused on the interval five years or more before the diagnosis of multiple sclerosis. Such diseases (eg, diabetes mellitus, allergy, bronchial asthma, epilepsy, thrombocytopenia) turned out to be a significant risk factor for the women. In a study of these diagnoses, however, no distinguishable pattern was observed. The odds ratio was nevertheless rather high when these various disorders were grouped together, and the interpretation could be that various diseases might play a role in precipitating clinically overt multiple sclerosis.

\section{Concluding remarks}

Exposure to solvents appears to be associated with an excess risk of developing multiple sclerosis. Both $\mathrm{X}$-ray treatment and radiological work show a risk, indicating that exposure to ionizing radiation might be a factor of interest in the pathogenesis of multiple sclerosis. In our earlier study, $\mathrm{X}$-ray examinations appeared as a risk indicator, and this finding supports the same hypothesis. In analogy with other investigations, we have demonstrated a risk from animal contacts, which was restricted to men with occupational contacts with cats or dogs, or contacts with caged birds. For livestock, however, the risk appears to be confounded by solvent use among farmers. Before firm conclusions about the risks from the exposures analyzed in this study can be made, further studies have to be performed.

\section{Acknowledgments}

We thank Dr S Ekbom, Division of Neurology, Hospital of Kalmar; Dr C Flodmark, Department of Clinical Chemistry, Ryhov Hospital, Jönköping; Dr G Skude, Department of Clinical Chemistry, Hospital of Kalmar; and Ms H Lundberg, Department of Neurology, University Hospital of Linköping, for helping to make the necessary data available.

The study was supported by grants from the Swedish Work Environment Fund.

\section{References}

1. Olerup O, Hillert J, Fredriksson S, Olsson T, KamHansen S, Möller E, et al. Primarily chronic progressive and relapsing/remitting multiple sclerosis: two immunogenetically distinct disease entities. Proc Natl Acad Sci USA 1989;86:7113-7.

2. Olerup O, Hillert J, Fredriksson. The HLA-D-regionassociated MS susceptibility genes may be located telomeric to the HLA-DP-subregion. Tissue Antigens 1990;35:37-9.

3. Olerup $\mathrm{O}$, Hillert J. HLA-D-region associated genetic susceptibility to multiple sclerosis: a critical evaluation. Tissue Antigens 1991;38:1-15.

4. La Mantia L, Illeni MT, Milanese C, Salmaggi A, Eoli M, Pellegris $\mathbf{G}$, et al. HLA antigens in Italian multiple sclerosis patients. Ital J Neurol Sci 1991;12:816.

5. Marrosu MG, Muntoni F, Murru MR, Costa G, Pischedda MP, Pirastu M, et al. HLA-DQB1 genotype in Sardinian multiple sclerosis: evidence for a key role of DQB $1 * 0201$ and *0302 alleles. Neurology 1992; 42:883-6.

6. Prineas J. Paramyxovirus-like particles associated with acute demyelination in chronic relapsing multiple sclerosis. Science 1972;178:760-3.

7. Helmick CG, Wrigley JM, Zack MM, Bigler WJ, Lehman JI, Janssen RS, et al. Multiple sclerosis in Key West, Florida. Am J Epidemiol 1989;130:935-49.

8. Murrell TG, Matthews BJ. Multiple sclerosis - one manifestation of neurobrucellosis? Med Hypotheses 1990;33:43-8.

9. Adams JM, Imagawa DT. Measles antibodies in multiple sclerosis. Proc Soc Exp Biol Med 1962;111:562.

10. Norrby E. Viral antibodies in multiple sclerosis. Prog Med Virol 1978;24:1.

11. Riise T, Grönning M, Klauber MR, Barrett-Connor E, Nyland H, Albrektsen G. Clustering of residence of multiple sclerosis patients at age 13 to 20 years in Hordaland, Norway. Am J Epidemiol 1991;133:9329.

12. Dhib-Jalbut $\mathrm{S}$, Lewis $\mathrm{K}$, Bradburn E, McFarlin DE, McFarland HF. Measles virus polypeptide-specific profile in multiple sclerosis. Neurology 1990;40:4305 .

13. Baig S, Olsson O, Olsson T, Löve A, Jeansson S, Link H. Cells producing antibody to measles and herpes simplex virus in cerebrospinal fluid and blood of patients with multiple sclerosis and controls. Clin Exp Immunol 1989;78:390-5.

14. Riikonen $R$. The role of infection and vaccination in the genesis of optic neuritis and multiple sclerosis in children. Acta Neurol Scand 1989;80:425-31.

15. Sola P, Merelli E, Faglioni P, Monti D, Cossarizza A, Franceschi C. DNA repair, sensitivity to gamma radiation and to heat shock in lymphocytes from acute, untreated multiple sclerosis patients. J Neuroimmunol 1989;21:23-9.

16. Reddy EP, Sandberg-Wollheim M, Mettus RV, Ray PE, De Freitas E, Koprowski H. Amplification and molecular cloning of HTLV-1 sequences from DNA in multiple sclerosis patients. Science 1989;243:529 33.

17. Dalgleish AG, Fazakerley JK, Webb HE. Do human T-lymphotrophic viruses and other enveloped viruses induce autoimmunity in multiple sclerosis? Neuropathol Appl Neurobiol 1987;13:241-50.

18. Kam-Hansen S, Lu CZ, Fredrikson S, Baig S. Retrovirus in multiple sclerosis. Acta Neurol Scand 1989;80:467-71.

19. McAlpine D, Lumsden C, Acheson ED. Multiple sclerosis, a reappraisal. Edinburgh, London: E \& S Livingstone Ltd, 1965:85.

20. Somer H, Müller K, Kinnunen E. Myasthenia gravis 
associated with multiple sclerosis: epidemiological survey and immunological findings. J Neurol Sci 1989; $89: 37-40$.

21. McCombe PA, Chalk JB, Pender MP. Familial occurrence of multiple sclerosis with thyroid disease and systematic lupus erythematosus. J Neurol Sci 1990; 97:163-71.

22. Miro J, Pena-Sagredo JL, Berciano J, Insua S, Leno Velarde R. Prevalence of primary Sjogren's syndrome in patients with multiple sclerosis. Ann Neurol 1990; 27:582-4.

23. Calin A. Is there an association between ankylosing spondylitis and multiple sclerosis? Ann Rheum Dis 1989;48:971-2.

24. Younger DS, Pedley TA, Thorpy MJ. Multiple sclerosis and narcolepsy: possible similar genetic susceptibility. Neurology 1991;41:447-8.

25. Olerup O, Schaffer M, Hillert J, Sachs C. The narcolepsy-associated DRw15, DQw6, Dw2 haplotype has no unique HLA-DQA or DQB restriction fragments and does not extend to the HLA-DP subregion. Immunogenetics 1990;32:41--4.

26. Dean G, Kurzke JF. On the risk of MS according to age at immigration to South Africa. Br Med J 1971; 3:725-9.

27. Cook SD, Dowling PC. A possible association between house pets and multiple sclerosis. Lancet 1977;1:9802.

28. Cook SD, Natelson BH, Levin BE, Chavis PS, Dowling PC. Further evidence of a possible association between house dogs and multiple sclerosis. Ann Neurol 1978;3:141-3.

29. Read D, Nassim D, Smith P, Paterson C, Warlow C. Multiple sclerosis and dog ownership: a case-control investigation. J Neurol Sci 1982;55:359-67.

30. Norman JE, Cook SD, Dowling PC. Household pets among veterans with multiple sclerosis and age matched controls. Arch Neurol 1983;40:213-4.

31. Lowis GE. The social epidemiology of multiple sclerosis. Sci Total Environ 1990;90:163—90.

32. Bergamini L, Durelli L. Multiple sclerosis: the immune pathogenetic hypothesis. Riv Neurol 1989;59:176-90

33. Amaducci L, Arfaioli C, Inzitari D, Marchi M. Multiple sclerosis among shoe and leather workers: an epidemiological survey in Florence. Acta Neurol Scand 1982;65:94-103.

34. Flodin U, Söderfeldt B, Noorlind-Brage H, Fredriksson M, Axelson O. Multiple sclerosis, solvents and pets: a case-referent study, Arch Neurol 1988;45: $620-3$.

35. Sheremata WA, Poskanzer DC, Withum DG, MacLeod $\mathrm{CL}$, Whiteside ME. Unusual occurrence on a tropical island of multiple sclerosis. Lancet 1985;2:618.

36. Lauer K. Risk of multiple sclerosis in relation to industrial activities: an ecological study in four European countries. Neuroepidemiology 1989;8:38-42.

37. Alaev BA, Aslanov AM. Climatic factors and clinical polymorphism of multiple sclerosis. Zh Nevropatol Psikhiatr 1990;90:9-12.
38. Irvine DG, Schiefer HB, Hader WJ. Geotoxicology of multiple sclerosis: the Henribourg, Saskatchewan, cluster focus: I. the water. Sci Total Environ 1989;84: 45-59.

39. Acheson ED. What does the pattern mean? In: Matthews WB, Acheson ED, Batchelor JR, Weller R, ed. McAlpine's multiple sclerosis. New York, NY: Churchill Livingstone, 1985:27.

40. Bates D. Lipids and multiple sclerosis. Ups J Med Sci Suppl 1990;48:173-87.

41. Lauer K. Dietary changes in temporal relation to multiple sclerosis in the Faroe Islands: an evaluation of literary sources. Neuroepidemiology 1989;8:200-6.

42. Martyn C. The epidemiology of multiple sclerosis. In: Matthews WB, ed. McAlpine's multiple sclerosis. 2nd edition. Edinburgh, London, Melbourne, New York: Churchill Livingstone, 1991:9.

43. Schumacher GA, Beebe G, Kibler RF, Kurland JF, Kurtzke JF, McDowell F, et al. Problems of experimental trials of therapy in multiple sclerosis: report by a panel on the evaluation of experimental trials of therapy in multiple sclerosis. Ann NY Acad Sci 1965; 122:552-68.

44. Rose AS, Ellison GW, Myers LW, Tourtellotte WW. Criteria for the clinical diagnosis of multiple sclerosis. Neurology (Minneap) 1976;26(6,pt2):20—2.

45. Ravnskov U, Forsberg B, Skerfving S. Glomerulonephritis and exposure to organic solvents. Acta Med Scand 1979;205:575-9.

46. Mantel N, Haenszel W. Statistical aspect of analysis of data from retrospective studies of disease. JNCI 1959;23:719-48.

47. Miettinen OS. Estimability and estimation in case-referent studies. Am J Epidemiol 1976;103:226-35.

48. Epicenter Software. Epilog Plus, statistical package for epidemiology and clinical trials. Pasadena, CA: Epicenter Software, 1990.

49. Miettinen OS. Theoretical epidemiology. New York, NY: Wiley \& Sons, 1985:46-83.

50. Wikkelsö C, Ekberg K, Lillienberg L, Wetterholm B, Karlsson B, Blomstrand C, et al. Cerebrospinal fluid proteins and cells in men subjected to long-term exposure to organic solvents. Acta Neurol Scand Suppl 1984;100:113-9.

51. Barregård L, Wikkelsö C, Rosengren LE, Aurell A, Thiringer G, Nilson L, et al. Cerebrospinal fluid proteins in men with chronic encephalopathy after exposure to organic solvents. Scand J Work Environ Health 1990;16:423-7.

52. Latarjet $\mathrm{R}$. Radiation in relation to cancerogenesis and mutation: a few points. In: University of Texas, ND Anderson Hospital and Tumor Institute. Genetics and cancer. London: Peter Owen Ltd, 1959:119—32.

53. Latarjet $R$. Possible mechanisms of radiation-induced malignancy at the cellular level. In: Emmelot P, Mühlbock $\mathrm{O}$, ed. Cellular control mechanisms and cancer. Amsterdam, London, New York: Elsevier, 1964:322-8.

Received for publication: 15 April 1993 